\title{
ODOUR EXPOSURE LEVEL MEASUREMENT SURROUNDING PALM OIL MILL
}

\author{
ANDREW YAP KIAN CHUNG*; NASTAEIN QAMARUZ ZAMAN**; ROHAYA MOHAMED HALIM*; \\ FATAH YAH ABD MANAF* and NU'MAN ABDUL HADI*
}

\begin{abstract}
Odorous gases such as ammonia and hydrogen sulphide produced by anaerobic bacteria are emitted when palm oil mill effluent is treated via anaerobic digestion. Although odour is a nuisance rather than a hazardous nature most of the times, sensory annoyance complaints provoke local authority to seek for feasible mitigation. Malaysian Department of Environment (DOE) under the jurisdiction of the Air Division has proposed an odour emission limit of $12000 \mathrm{OUm}^{-3}$ for palm oil mills recently. The objective of this paper is to establish the anaerobic pond odour concentration at palm oil mill using open ponding system for POME treatment, identify ammonia $\left(\mathrm{NH}_{3}\right)$ and hydrogen sulphide $\left(\mathrm{H}_{2} \mathrm{~S}\right)$ gas content in odour sample collected from respective anaerobic pond, and establish the odour concentration (OUm ${ }^{-3}$ ) at residential locations close to a palm oil mill using open ponding system, covered lagoons and tank digester for POME treatment. The odour sampling and assessment were performed according to MS 1963:2007 Air Quality - determination of odour concentration by dynamic olfactometry with enhanced VDI3940 Grid Method. Results showed that odour concentration at source of anaerobic pond ranged from 44 135-85012 $\mathrm{OUm}^{-3}$ while hydrogen sulphide content ranged from 15.9-103.9 ppm and ammonia content ranged from 4.1-16.6 ppm. Odour concentrations at residential locations are often dominated by local odour sources such as chicken farms. Odour emission levels at all surveyed residential areas identified as palm oil mills origin were well below $10 \mathrm{OUm}^{-3}$ most of the times although high level of up to $108.4 \mathrm{OUm}^{-3}$ has been observed occasionally. Thus the proposed odour limit value needs to be reviewed and justified based on further study with focus on more data collection, odour control guidelines, community odour impact survey, inclusion limit values for odorous chemical substances, odour regulation framework, odour assessment methods and odour management plan guidelines.
\end{abstract}

Keywords: anaerobic digestion, European reference odour mass, odour nuisance, olfactometry, POME treatment.

Date received: 20 December 2019; Sent for revision: 24 December 2019; Accepted: 30 July 2020.

\section{INTRODUCTION}

For every tonne of fresh fruit bunches (FFB) processed at palm oil mills, $0.6 \mathrm{t}$ of palm oil mill

\footnotetext{
Malaysian Palm Oil Board,

6 Persiaran Institusi, Bandar Baru Bangi,

43000 Kajang, Selangor, Malaysia.

E-mail: andrew@mpob.gov.my

** School of Civil Engineering,

Universiti Sains Malaysia, Engineering Campus,

14300 Nibong Tebal, Pulau Pinang,

Malaysia.
}

effluent (POME) is generated to produce crude palm oil (CPO). This acidic effluent contains water, oil, protein and traces of minerals (Fatah et al., 2012).

The average biochemical oxygen demand (BOD) of POME is about 25000 ppm and needs to be treated in order to reduce its BOD to below 20 ppm before being discharged into water course. Conventionally, it is treated in a series of anaerobic and aerobic ponds that require long hydro retention time (Loh et al., 2014). Open effluent pond digestion treatment is the most common treatment system practiced by Malaysian mills due to the low capital expenditure (CAPEX) and operation 
expenditure (OPEX) where the POME is digested by a consortium of the microorganisms commonly found in soil and air. Due to the recent biogas capture policy to further address sustainability issues, various treatment systems have been installed in palm oil mills, such as covered lagoon and digester tank systems. Practical data show that $1 \mathrm{~m}^{3}$ of POME could generate $25 \mathrm{~m}^{3}$ of biogas with average calorific value of $22000 \mathrm{kJm}^{-3}$ containing $62.5 \%$ methane, $37.0 \%$ carbon dioxide and traces of hydrogen sulphide and ammonia (Loh et al., 2017).

Anaerobic digestion is a complex biochemical process with a consortium of micro-organisms converting organic compounds in the absence of oxygen into methane and carbon dioxide in four stages, which are hydrolysis, acidogenesis, acetogenesis and methanogenesis (Loh et al., 2014). Anaerobic POME treatment releases odorous gases such as ammonia and hydrogen sulphide that are known as air pollutants which have become a serious environmental concern for many years. Malaysian Department of Environmental (DOE) is currently simulating the odour limit and sampling site to be gazetted in the new regulation. Environmental factors such as wind speed and direction, topography, atmospheric stability and pollutant concentration need to be considered during odour assessment.

Smell sensing is accomplished with two main nerves. Chemicals perception is processed by the olfactometry nerve whereas chemicals irritation or pungency is processed by the trigeminal nerve. All olfactory signals meet in the olfactory bulb where the information is distributed to two different parts of the brain. Limbic system pathway processes emotion and memory response of the body. The other information pathway is to the frontal cortex. From nostril to the brain signal, the process takes only about 500 milliseconds (Mauskar, 2008). Odour intensity is the perceived odour sensation strength which is related to the odorant concentration as shown in Equation (1) known as Stevens' law or the power law where $I$ is the intensity, $k$ is a constant, $C$ is the concentration, $n$ is exponent ranges from about 0.2 to 0.8 depending on the odorant.

$$
I=k(\mathrm{C})^{\mathrm{n}}
$$

Equation (1)

The odour concentrations mentioned as odour units per cubic meter is based on correlation between a physiological response when the nose detects odour, and exposure concentration of a particular sample. Odour unit is the amount of odorant(s) when evaporated into 1 cubic meter of neutral gas at standard conditions, elicits a physiological response equivalent to that elicited by one European Reference Odour Mass (EROM) which is equivalent to $123 \mu \mathrm{g} n$-butanol evaporated in one cubic meter of neutral gas at standard conditions.

In the Draft Environmental Quality (Odour) Regulations 201X (unpublished data), a limit of $12000 \mathrm{OUm}^{-3}$ was proposed, meaning no part or activities in palm oil mills can emit odour beyond the $12000 \mathrm{OUm}^{-3}$ thresholds. Thus, Malaysian Palm Oil Board (MPOB) and Universiti Sains Malaysia (USM) started an odour investigation project in order to produce reliable odour emission data to validate Department of Environment's proposal. Three mills with different treatment systems: open lagoon, covered anaerobic lagoon and anaerobic tank digester, were studied. However, findings from the previous preliminary survey (Andrew et al., 2019) demonstrated the inability of the mills to comply with the DOE proposed value. Thus, an alternative approach to the odour threshold limit is necessary to justify the odour pollution from palm oil mills.

Odour is a nuisance rather than a hazardous nature most of the times. Nuisance is defined as cumulative effect on human caused by repeated annoyance events over an extended period of time that leads to modified or altered behaviour (Van Harreveld, 2001). Thus, the odour exposure to the surrounding community is also a measurable data to validate odour emission issue from the palm oil mill. It seems probable that despite being noncompliant at source, odour may be minimal below the threshold at the boundary, which is less likely to be a nuisance to the surrounding community. The Nuisance Law approach will be implemented in Malaysia odour legislation.

The objectives of the survey are: (1) To establish the anaerobic pond odour concentration $\left(\mathrm{OUm}^{-3}\right)$ at palm oil mill using open ponding system for POME treatment, (2) To identify ammonia $\left(\mathrm{NH}_{3}\right)$ and hydrogen sulphide $\left(\mathrm{H}_{2} \mathrm{~S}\right)$ gas concentration in odour sample collected from respective anaerobic ponds, and (3) To establish odour concentration $\left(\mathrm{OUm}^{-3}\right)$ at residential locations close to palm oil mill using open ponding system, covered lagoons and tank digester for POME treatment. Wind speed and direction at every location was also recorded.

\section{MATERIALS AND METHODS}

Odour measurement method, project site and measuring instruments need to be duly determined prior to the survey execution. Odour measurements consist of in field odour measurement and emission point odour sampling measurement. The project schedule should cover normal and peak crop seasons in order to produce a comprehensive survey. Although weather conditions are uncontrollable, wind blow condition would be recorded. 


\section{Odour Measurement Methods}

A defined odour measurement method is described in standard MS 1963:2007 (olfactometry) set out by the Department of Standards Malaysia (SIRIM) using $n$-butanol for equipment calibration and panel member selection. The odour assessment results are expressed in terms of $\mathrm{OUm}^{-3}$ European Reference Odour Mass (EROM) where one EROM is equivalent to $123 \mu \mathrm{g} n$-butanol.

\section{In Field Odour Measurement}

Direct real time in-field odour measurement using olfactometer for ambient and boundary investigation was conducted. Enhanced VDI3940 Grid Method was adopted to execute in field odour survey which included the determination of odour intensity, odour concentration and odour characters for a $10 \mathrm{~min}$ observation period at each location.

The Scentroid SM100 in-field olfactometer incorporates a dilution device within a portable device, allowing direct odour concentration measurements to be carried out in real time in the field. The odour assessment method involved the determination of odour intensity, odour concentration and odour characterisation following that of Balch et al. (2015) and Bakhtari and Medina (2016). Three odour concentration $\left(\mathrm{OUm}^{-3}\right)$ readings were recorded and further supported by odour intensity of 0 (no odour) to 6 (extremely strong). Odour characters such as 'sour vinegar, rotten egg or others were also noted during the field survey to better understand the odour impact to the surrounding communities. The odour survey form recorded the odour intensity and character, with a short description of the various scales and numbers described in the survey form for easy reference. The potential odour sources from on-site observation would also be recorded to further support the detection of odour and understanding possible nearby contributors.

\section{Odour Sampling at Emission Point and Laboratory} Analysis

Odour sampling at emission point and laboratory analysis in an odour free room was conducted for odour emission strength identification and odour control systems design. Samples were collected into 10 litre Nalophan bag and sent to the odour laboratory for olfactometry analysis using the Scentroid SS400 dynamic olfactometer to determine their concentration, expressed as $\mathrm{OUm}^{-3}$.

Hydrogen sulfide and ammonia levels in the odour samples were analysed using a portable multi-sensor device, the OdoTracker TR8 (Scentroid, Canada).

\section{Instruments Accuracy}

The SM 100 Scentroid Olfactometer with detection range from 3.5-11 $355 \mathrm{OUm}^{-3}$ was used for in field measurement whereas the Scentroid SS400 dynamic olfactometer with detection range from 15-18 $643 \mathrm{OUm}^{-3}$ was used for source samples measurement within $30 \mathrm{hr}$ of sample collection. Due to the predicted odour samples strength, pre-dilution was necessary prior to analysis. The Geometric Mean as shown in Equation (2) is used to compare and analyse the data properties.

Geometric Mean, GM $=\sqrt[n]{a_{1} \times a_{2} \times \ldots \times a_{n}}$

$\Delta \mathrm{z}_{i}=\frac{a_{i}}{G M}$ if $a_{i} \geq G M ; \Delta \mathrm{z}_{i}=\frac{G M}{a_{i}}$ if $a_{i}<G M$; Equation (2)

$1 \leq \Delta z_{i} \leq 1.5$

OdoTrackerTR8 (Scentroid, Canada) is equipped with electrochemical sensors for hydrogen sulfide detection range from 1-2000 ppm with resolution of 1 ppm and ammonia detection range from 0-100 ppm with resolution of 0.3 ppm.

\section{Project Sites}

Odour exposure measurements in the survey were carried out at three palm oil mills and selected boundaries as described in Table 1. The mills differed in terms of effluent treatment system which affected the odour emission from the anaerobic ponds. The survey boundaries for each location was selected within $2 \mathrm{~km}$ radius and determined based on the safe assessment into the established residential area. Thus, the boundaries distances were different for each study location.

TABLE 1. SURVEY LOCATIONS

\begin{tabular}{lccc}
\hline POME treatment & Location & $\begin{array}{c}{ }^{\mathrm{A}} \text { Boundary } \\
\mathbf{1}\end{array}$ & $\begin{array}{c}{ }^{\mathrm{A}} \text { Boundary } \\
\mathbf{2}\end{array}$ \\
\hline Open pond & Mill A, Kedah & $0.8 \mathrm{~km} \mathrm{NE}$ & $2.0 \mathrm{~km} \mathrm{~W}$ \\
Covered lagoon & Mill B, Penang & $0.7 \mathrm{~km} \mathrm{~W}$ & $1.0 \mathrm{~km} \mathrm{E}$ \\
Digester tank & Mill C, Perak & $1.4 \mathrm{~km} \mathrm{~N}$ & $1.9 \mathrm{~km} \mathrm{SW}$ \\
\hline
\end{tabular}

Note: ${ }^{\mathrm{A}}$ Boundary 1: nearest residence, Boundary 2: second-nearest residence to palm oil mill.

The anaerobic pond odour complete with odorous gases contents assessments and in field boundary odour assessments for the respective three selected palm oil mills were duly carried out according to the schedule as shown in Table 2.

During in field odour concentration measurement, odour intensity was also recorded every $10 \mathrm{~s}$ for $10 \mathrm{~min}$ to a scale of 0-6 following UK Environment Agency guideline as shown in Table 3. 
TABLE 2. PROJECT SCHEDULE IN YEAR 2019

\begin{tabular}{|c|c|c|c|c|}
\hline \multirow{2}{*}{$\begin{array}{c}\text { Project } \\
\text { assessment }\end{array}$} & \multicolumn{2}{|c|}{ Normal crop } & \multicolumn{2}{|c|}{ Peak crop } \\
\hline & Start & End & Start & End \\
\hline Boundaries Mill A & 19 Feb. & 21 Feb. & 13 Aug. & 15 Aug. \\
\hline Boundaries Mill C & 25 Mar. & 27 Mar. & 08 Jul. & 10 Jul. \\
\hline
\end{tabular}

TABLE 3. ODOUR INTENSITY DESCRIPTION

\begin{tabular}{cll}
\hline Intensity & Odor strength & Description \\
\hline 0 & No odour & Odour detection threshold (ODT) \\
1 & Very weak & Some doubt whether odour is actually present \\
2 & Weak & Odour is present but cannot be described precisely \\
3 & Distinct & The odour character is barely recognisable \\
4 & Strong & The odour character is easily recognisable \\
6 & Very strong & Odour is offensive and the exposure level is undesirable \\
6 & Extremely strong & $\begin{array}{l}\text { Odour is offensive and instinctive reaction would mitigate against further } \\
\text { exposure }\end{array}$
\end{tabular}

\section{RESULTS AND DISCUSSIONS}

Malaysia has tropical monsoon climate which is hot with normal ambient temperature ranging from $25^{\circ} \mathrm{C}-35^{\circ} \mathrm{C}$, humidity up to $85 \%$ and rain throughout the year. The highest ambient temperature is usually recorded from 12:00-15:00 and the sun heating effect is negligible during 19:00-07:00. Thus, the microorganisms' activities within the POME treatment ponds vary from day to night but remained in similar trend throughout the year.

Odour intensity level 0-2 was recorded most of the time and intensity level 3 was occasionally recorded during in field assessments.

A bio-digester has been installed at Mill A since the first run during normal crop season as part of the palm oil mill effluent treatment system, which includes a covered anaerobic lagoon and a gas collection system. The bio-digester precedes five open anaerobic lagoons, a facultative pond, aeration pond, and two settling ponds before final discharge. At the time of the odour assessment in the second run during peak crop season, the same effluent treatment plant configuration was present, and although the bio-digester was completed, it was in the commissioning stage and yet to be fully operational. However, the odour concentration at source and in-field reduced significantly during the second assessment as shown in Figure 4 compared to Figure 3. Similar observation was also found on $\mathrm{H}_{2} \mathrm{~S}$ and $\mathrm{NH}_{3}$ content in gas samples collected from anaerobic pond as shown in Figure 2 compared to previous assessment as shown in Figure 1. Thus, biogas capture reduced odour emission from palm oil mill via quarantine approach.

Figures 5 and 6 show the boundary odour assessments for covered lagoon system during normal crop and peak crop season, respectively. Figures 7 and 8 show the boundary odour assessments for digester tank system during normal crop and peak crop season, respectively. Results showed that the odour concentration at source was very much higher than in-field odour concentration. The odorous gases content varies with in-field odour concentration profile and is affected by environmental factors which influence microorganisms' activities such as temperature, humidity and air pressure due to wind blow.

Samples analysis showed that hydrogen sulphide $\left(\mathrm{H}_{2} \mathrm{~S}\right)$ content was always higher than ammonia $\left(\mathrm{NH}_{3}\right)$ content. Both odorous gases content is in ppm. Thus, the disappearance of the odour effect is mainly due to gases dilution with atmospheric air. Ammonia threshold is $500-1000$ ${\mu \mathrm{gm}^{-3}}^{-3}$ whereas hydrogen sulphide threshold is 1.5$150 \mathrm{\mu gm}^{-3}$ (Ding et al., 2012). However, small portion of the odorous gases are decomposed via bacterial activities. Sulphur bacteria oxidise hydrogen sulphide via pathway as shown in Equation (3) (Startsev, 2017).

$$
2 \mathrm{H}_{2} \mathrm{~S}+\mathrm{O}_{2} \rightarrow 2 \mathrm{~S}+2 \mathrm{H}_{2} \mathrm{O}
$$

Equation (3) 
Odour Concentration and Odourous Gases Contents

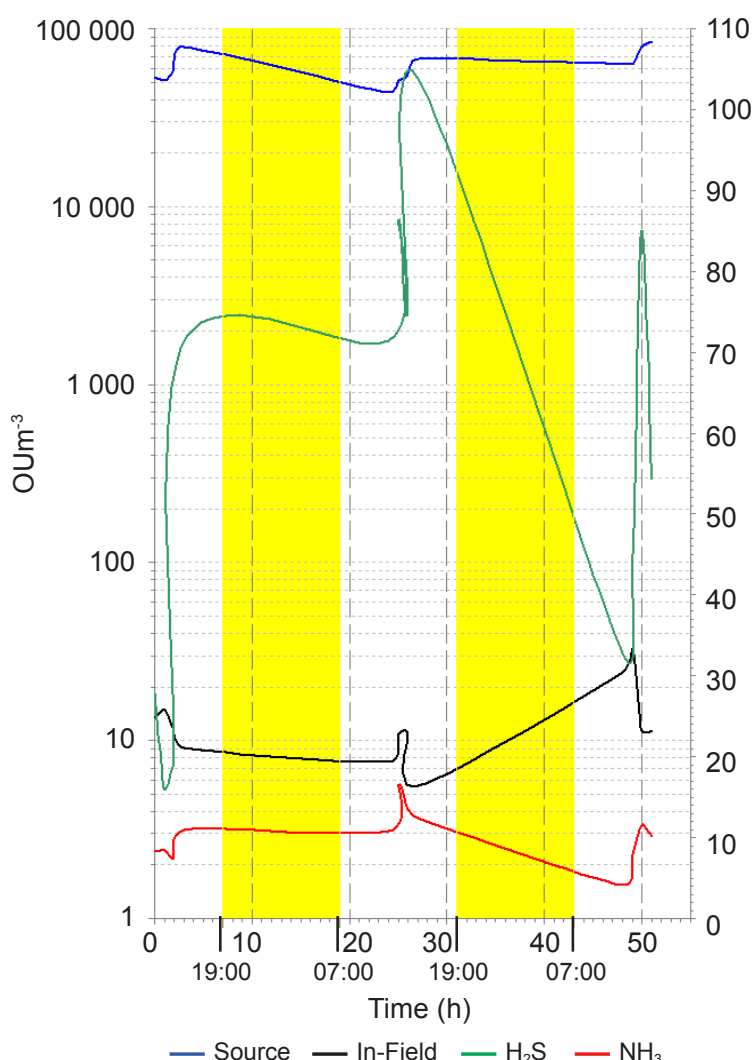

Figure 1. Normal crop anaerobic pond odour concentration and odourous gas content.

In Field Odour Concentration

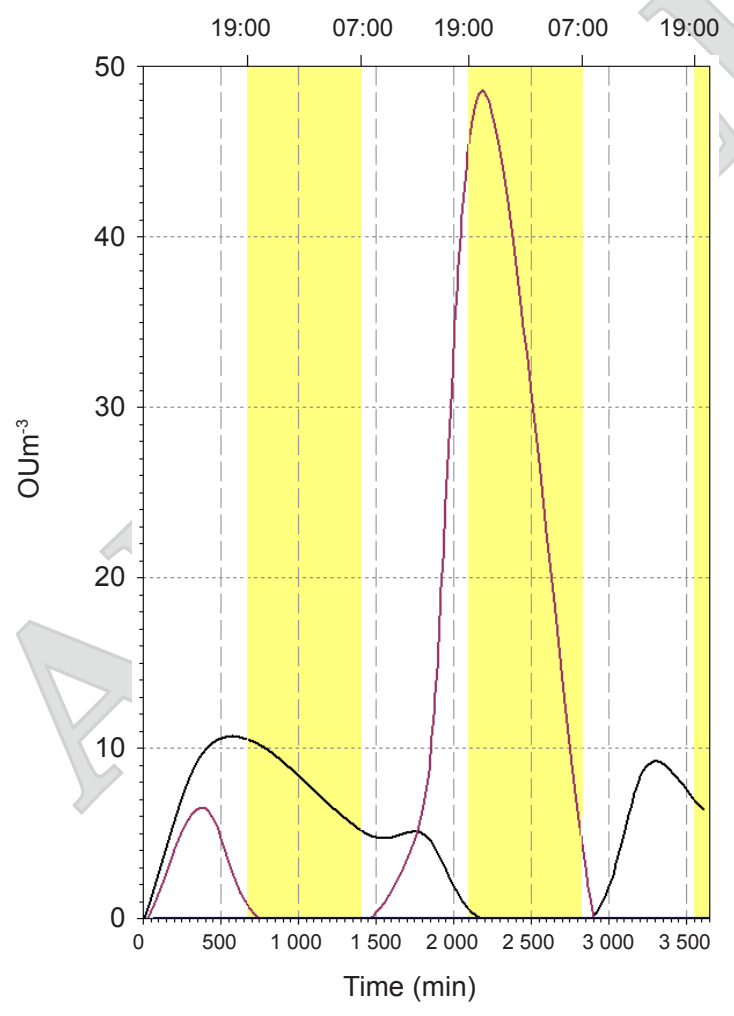

- B0 - B1 - B2

Figure 3. Boundary odour assessments for open pond system during normal crop.
Odour Concentration and Odourous Gases Contents

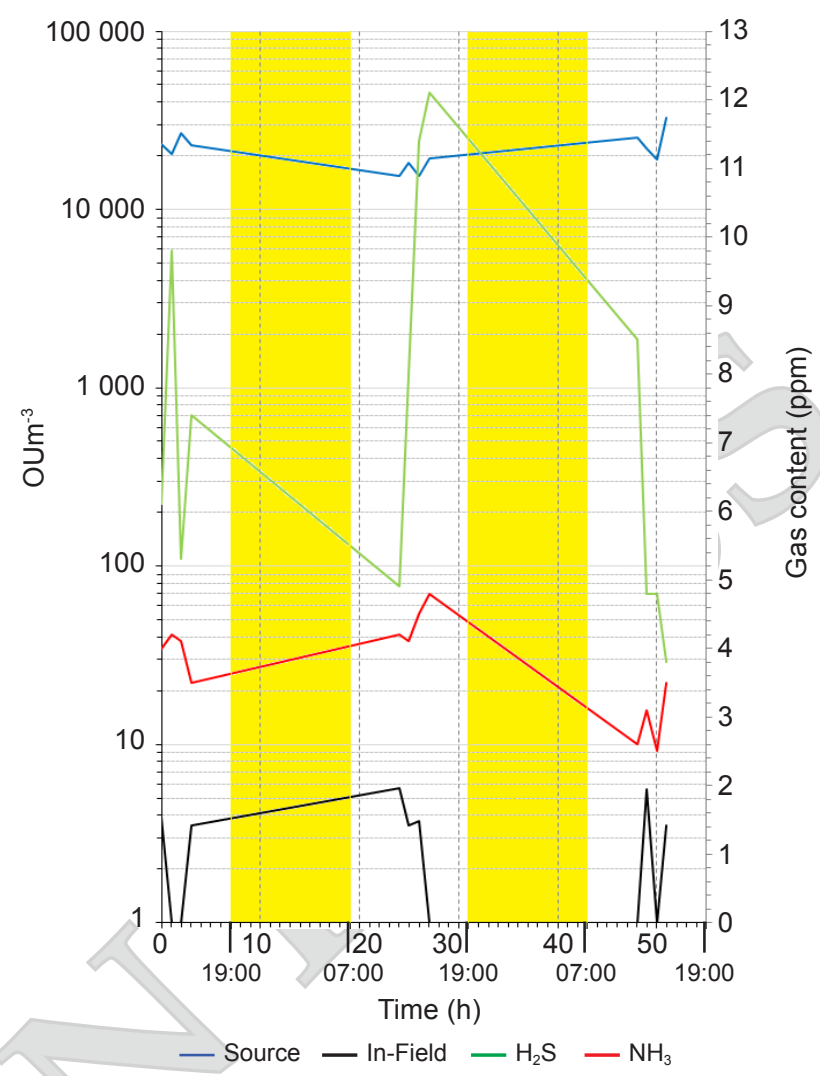

Figure 2. Peak crop anaerobic pond odour concentration and odourous gas content.

In Field Odour Concentration

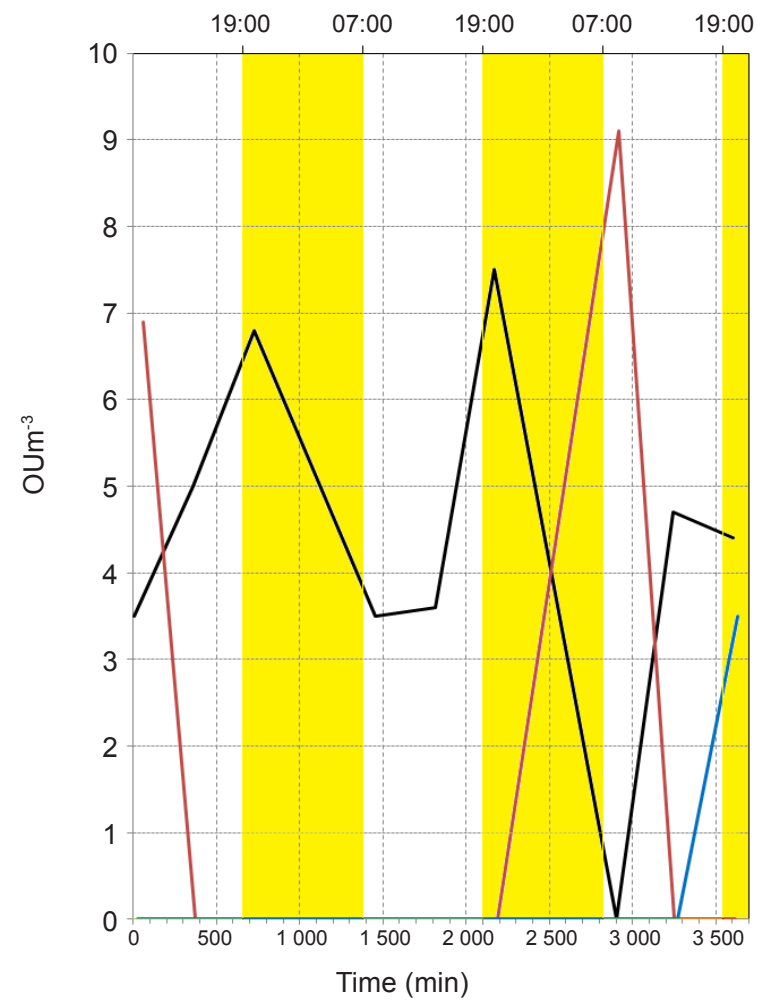

- B0 - B1 - B2

Figure 4. Boundary odour assessments for open pond system during peak crop. 
In Field Odour Concentration

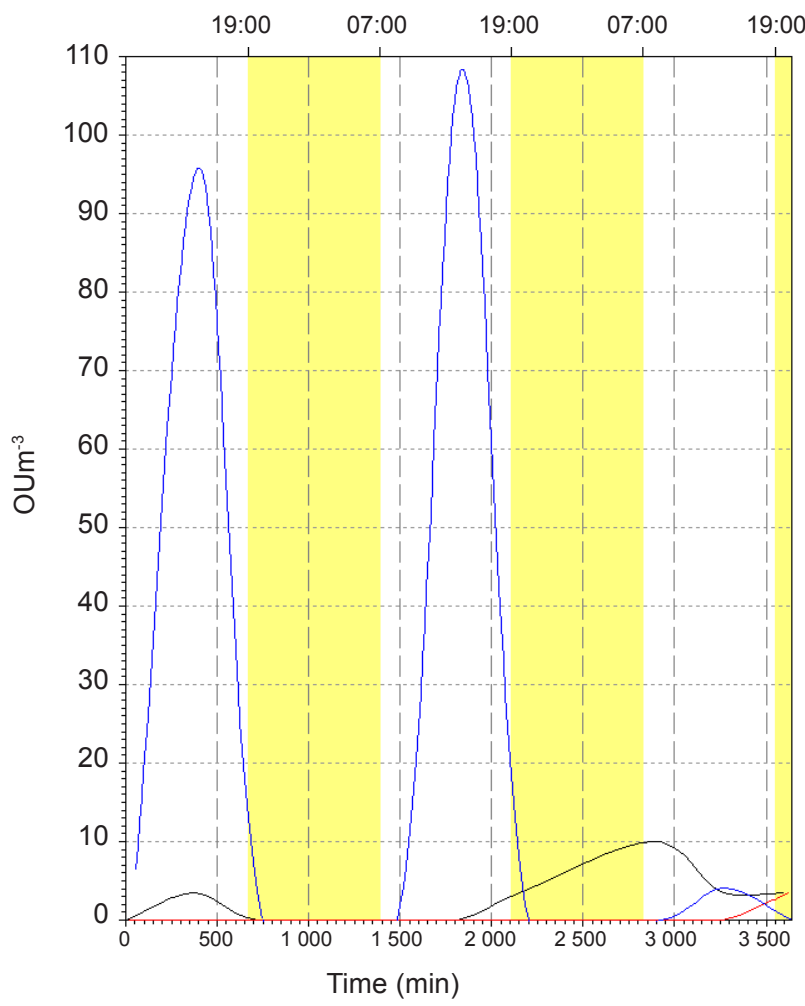

- B0 - B1 - B2

Figure 5. Boundary odour assessments for covered lagoon system during normal crop.

In Field Odour Concentration

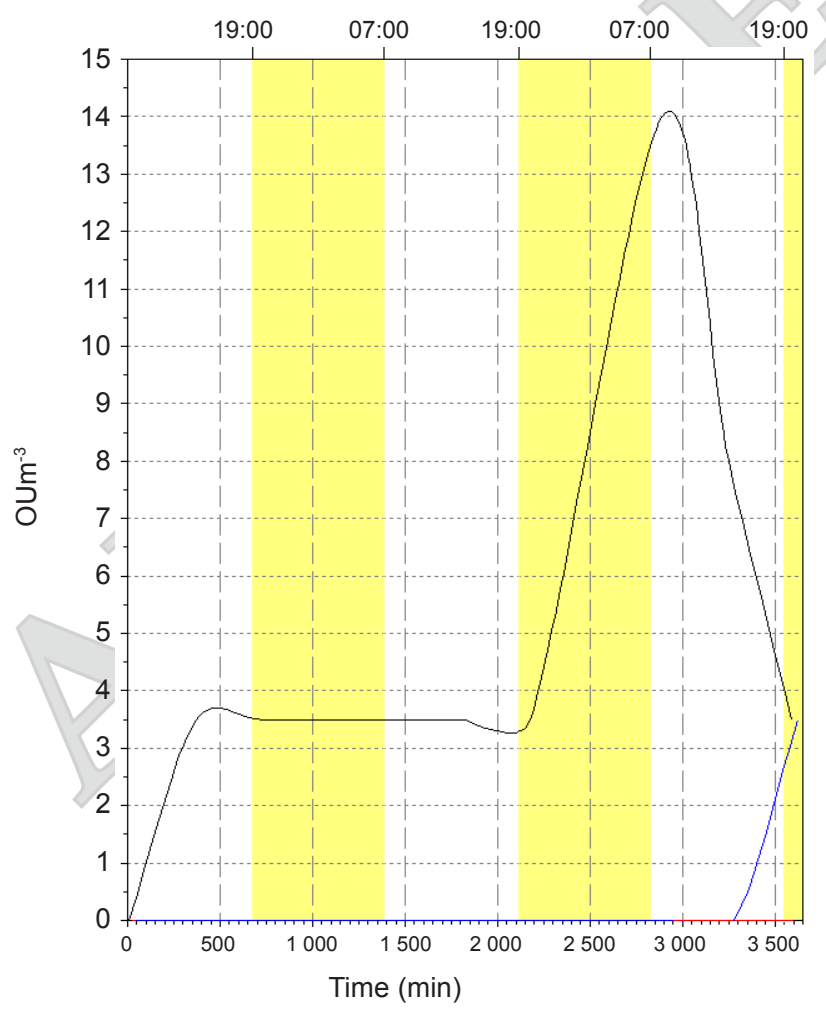

$-\mathrm{B} 0-\mathrm{B} 1-\mathrm{B} 2$

Figure 7. Boundary odour assessments for digester tank system during normal crop.
In Field Odour Concentration

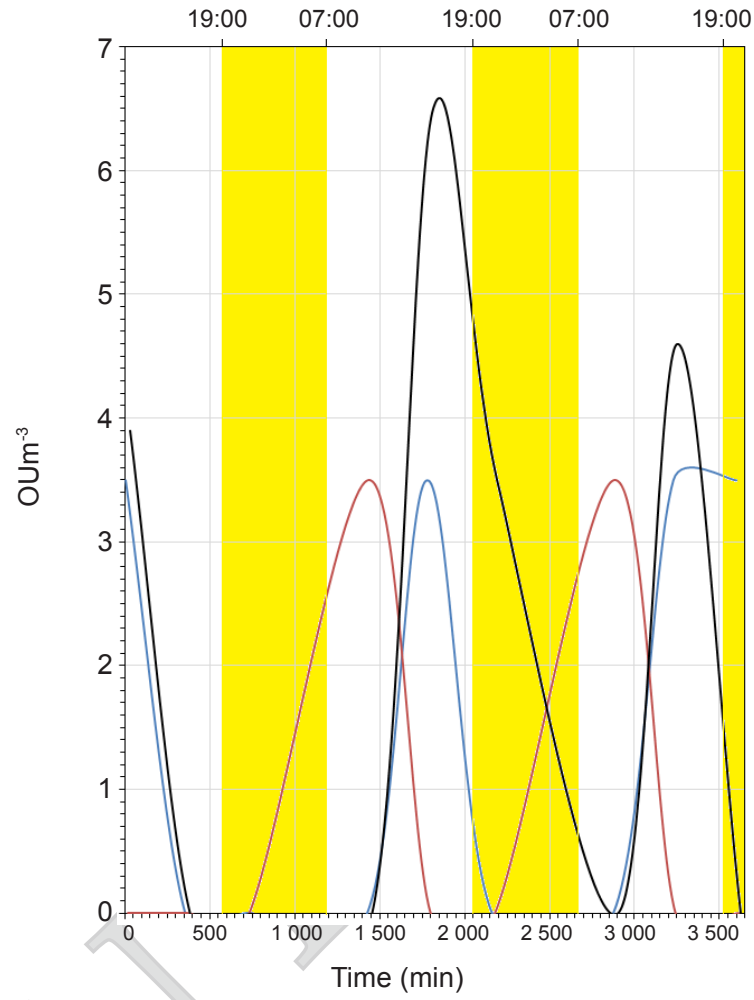

$-\mathrm{B} 0-\mathrm{B} 1-\mathrm{B} 2$

Figure 6. Boundary odour assessments for covered lagoon system during peak crop.

In Field Odour Concentration

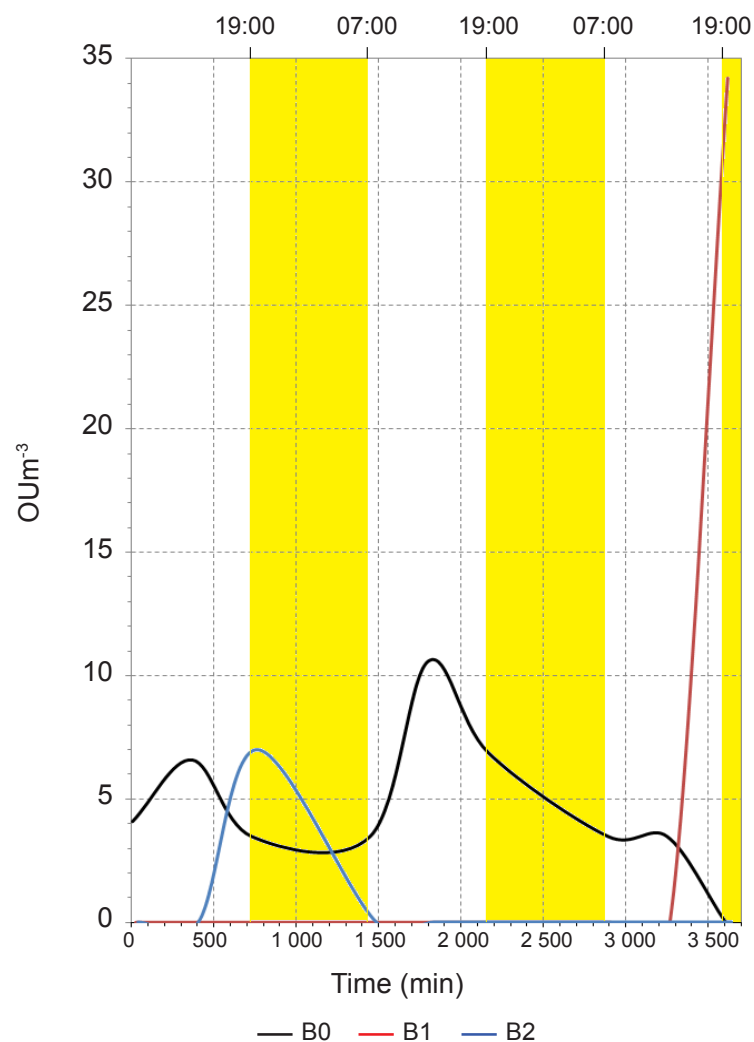

Figure 8. Boundary odour assessments for digester tank system during peak crop. 
Ammonia is oxidised by nitrifying bacteria via complex autotrophic nitrification process that requires several enzymes, proteins and oxygen as shown in Equation (4).

$$
\begin{gathered}
\mathrm{NH}_{3}+\mathrm{O}_{2}+2 \mathrm{H}^{+}+2 \mathrm{e}^{-} \rightarrow \mathrm{NH}_{2} \mathrm{OH}+ \\
\mathrm{H}_{2} \mathrm{O} \rightarrow \mathrm{NO}_{2^{-}}+5 \mathrm{H}^{+}+4 \mathrm{e}^{-}
\end{gathered}
$$

Equation (4)

Based on the empiric data and the threshold limits, the odour emission from palm oil mill is dominated by hydrogen sulphide. Figure 9 shows the correlation between the odorous gas content and odour concentration of the gas samples collected from anaerobic pond. Low correlation between the respective odorous gas and odour concentration indicated that the odour of the gas samples collected from the anaerobic pond were not single odorant effect but rather a combination of various odorous gases generated from POME anaerobic fermentation. Although the amount of such odorous gases was regulated by the microbial activity, the odour concentration theoretically was proportional to the amount of odorant present in the gas sample. Thus, linear multivariate regression has been performed yielding empiric odour model as shown in Equation (5) where $x_{1}$ is hydrogen sulphide, $\mathrm{H}_{2} \mathrm{~S}$ content in ppm; $x_{2}$ is ammonia, $\mathrm{NH}_{3}$ content in ppm and y is odour concentration in $\mathrm{OUm}^{-3}$.

$y=372.9286 x_{1}+1718.5450 x_{2}+17419.7682 \quad$ Equation (5)

\begin{tabular}{lcccc}
\hline Source & $\begin{array}{c}\text { Degree } \\
\text { of } \\
\text { freedom }\end{array}$ & $\begin{array}{c}\text { Sum of } \\
\text { square }\end{array}$ & $\begin{array}{c}\text { Mean } \\
\text { square }\end{array}$ & F value \\
\hline Regression & 2 & 8551324254 & 4275662127 & 17.71520843 \\
Residual & 22 & 5309819930 & 241355451.4 & \\
\hline Total & 24 & 13861144184 & & \\
\hline
\end{tabular}

The $R^{2}$ value increases to 0.7854 with estimation error 14573.7023 showed that besides $\mathrm{H}_{2} \mathrm{~S}$ and $\mathrm{NH}_{3}$, other unidentified odorous gases also existed and influenced the odour concentration.

Wind rose diagram for survey locations of Mill A, Mill B and Mill C is shown in Figures 10, 11 and 12, respectively. Diagrams analysis show that only Mill A Boundary 1 and Mill B Boundary 2 have potential of odour complaints due to wind blow. However, the wind speed at all survey sites was well below $5 \mathrm{mph}$ most of the time even strong wind was recorded at Mill A; once $21.15 \mathrm{mph}$ South and once $5.3 \mathrm{mph}$ South to Southeast (SSE).

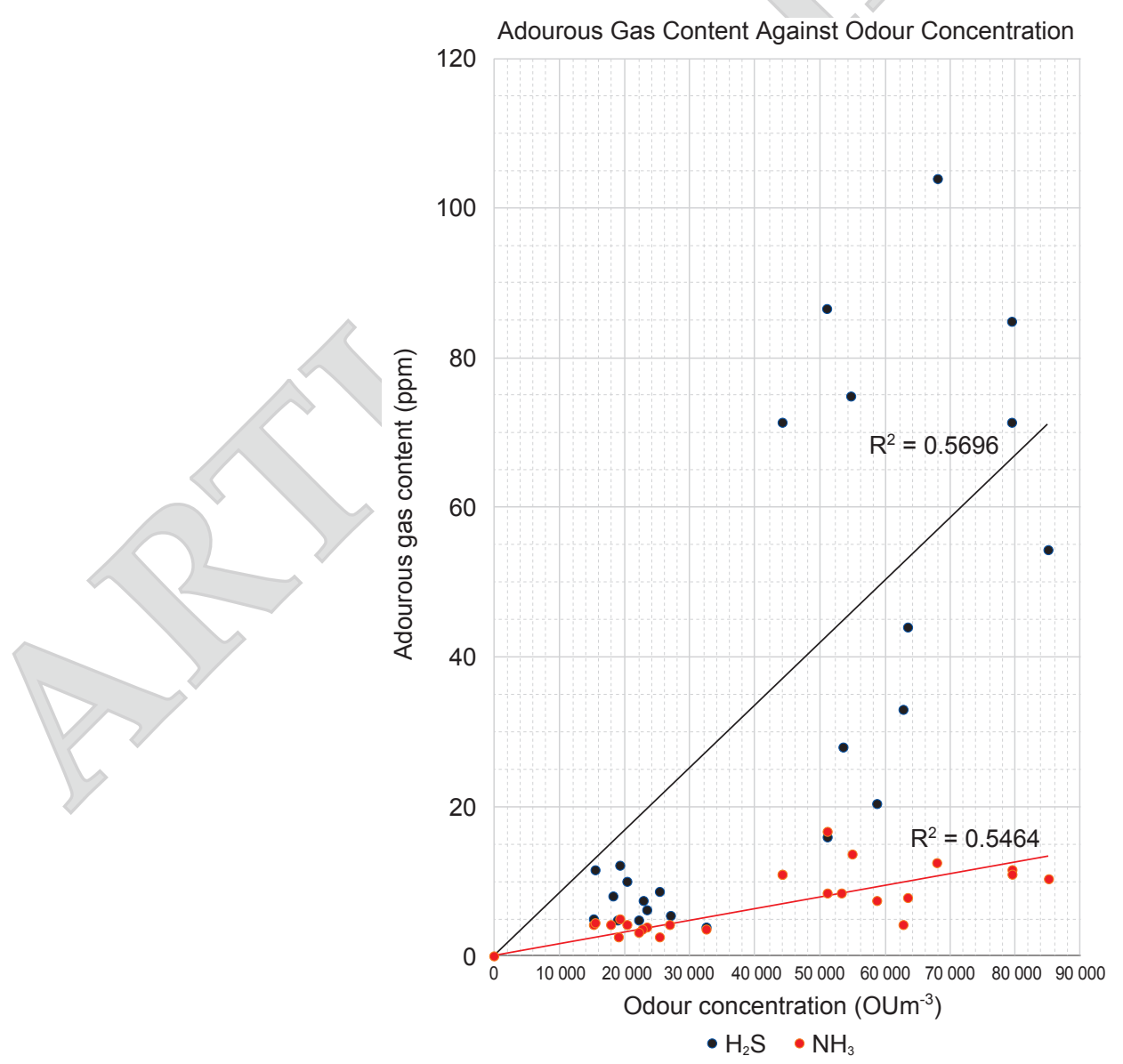

Figure 9. Correlation between odourous gas content and odour concentration. 


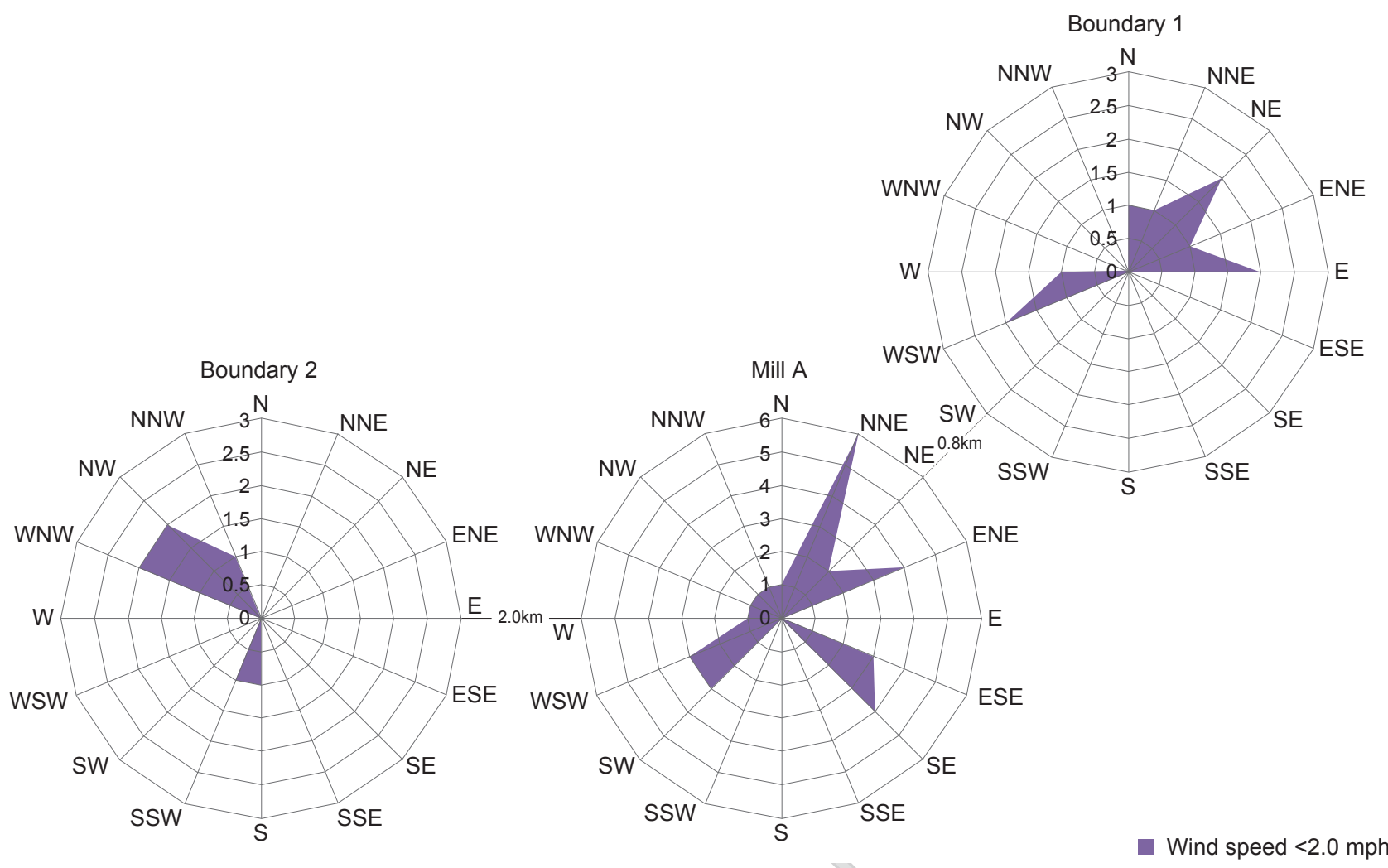

Figure 10. Wind Rose Diagram Analysis for Mill A and the survey boundary areas.

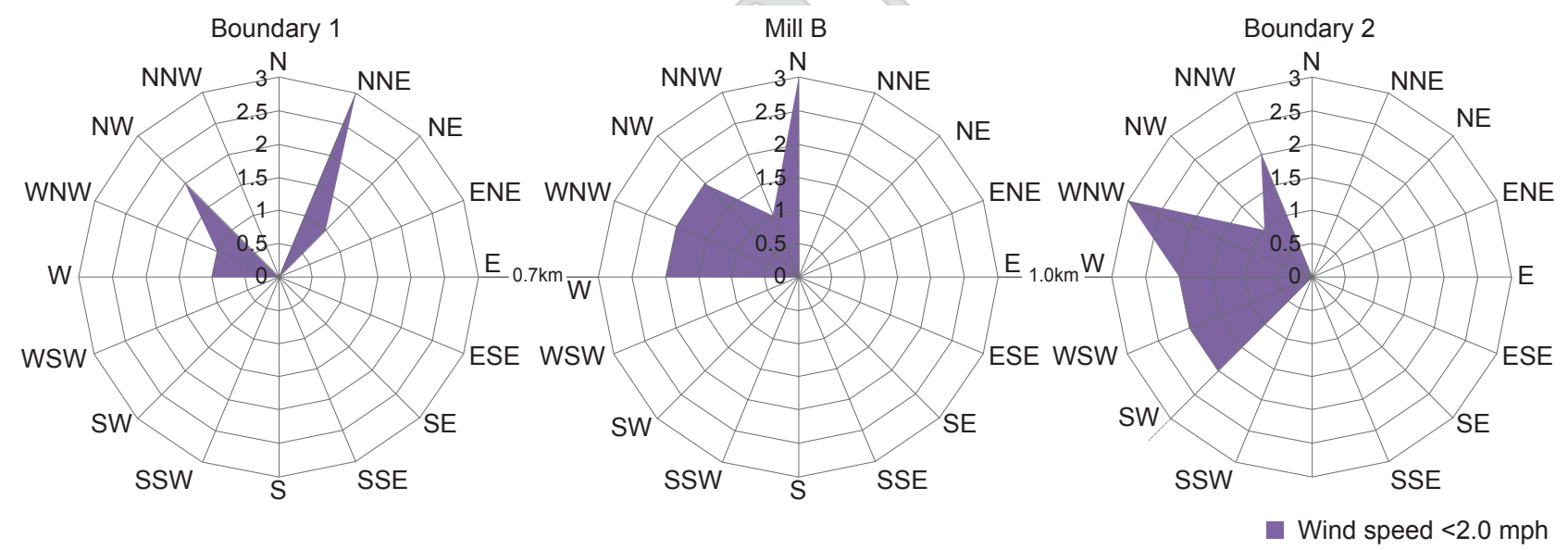

Figure 11. Wind Rose Diagram Analysis for Mill B and the survey boundary areas.

\section{CONCLUSION}

Experimental results showed that odour concentration at source of anaerobic pond ranged from 44 135-85 $012 \mathrm{OUm}^{-3}$ while hydrogen sulphide content ranged from 15.9-103.9 ppm and ammonia content ranged from 4.1-16.6 ppm. Odour concentrations at residential locations are often dominated by local odour sources such as chicken farms. Odour emission levels at all surveyed residential areas identified as palm oil mills origin were well below $10 \mathrm{OUm}^{-3}$ most of the times although high level of up to $108.4 \mathrm{OUm}^{-3}$ has been observed occasionally.

\section{ACKNOWLEDGEMENT}

Authors would like to express the sincerest gratitude to the Director-General of MPOB for the support in project execution.

\section{REFERENCES}

Andrew, Y K C; Nastaein, Q Z; Nurashikin, Y; Syafinah, Y; Fatah, Y A M; Rohaya, M H and Rusnani, A M (2019). The effectiveness of gas recovery systems for managing odour from conventional effluent treatment ponds in palm 


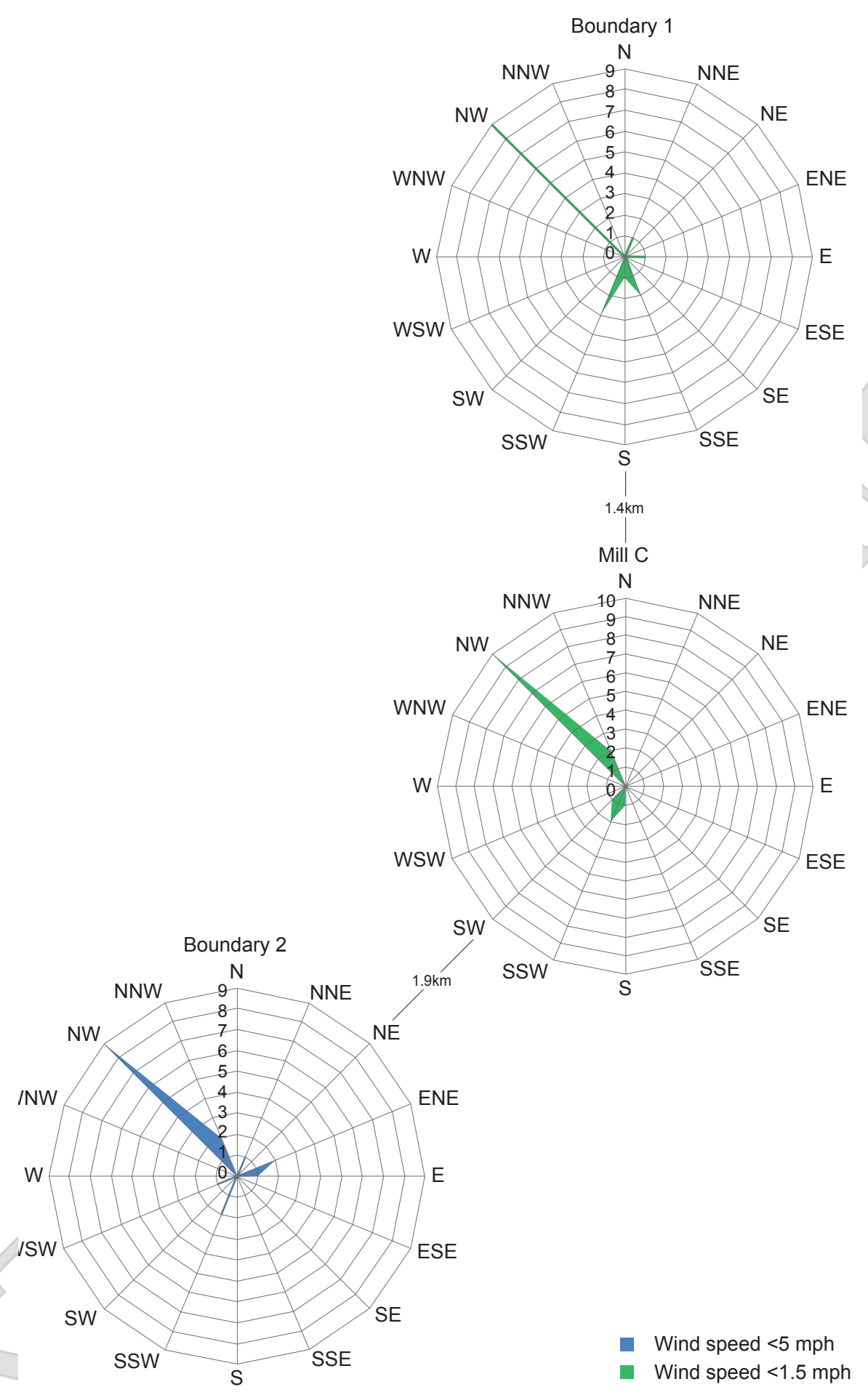

Figure 12. Wind Rose Diagram Analysis for Mill C and the survey boundary areas.

oil mills in Malaysia. Civil and Environmental Engineering Reports, 30(3): 070-085.

Bakhtari, A and Medina, S (2016). Enhancing VDI3940 grid method via in-field olfactometry to obtain complete odour impact assessment. Chemical Engineering Transactions, Vol. 54: 283-288.

Balch, A; Gary, G and Bianca, K (2015). FIDOL Factors, odour nuisance and risk: The adaptation of field based odour assessments using a field Olfactometer. A discussion and case study. Proc. of CASANZ2015 Conference. Melbourne, 20-23 September 2015.

Ding, Y; Cai, C; Hu, B; Xu, Y; Zheng, X; Chen, $Y$ and $\mathrm{Wu}, \mathrm{W}$ (2012). Characterization and control of odorous gases at a landfill site: A case study in Hangzhou, China. Waste Management, 32: 317326. 
Fatah, Y A M; Andrew, Y K C and Ravi, M N (2012). Spray drying palm oil mill effluent. Palm Oil Engineering Bulletin, 100: 11-32.

Loh, S K; Nasrin, A B; Nurul, A B; Mohamed, A S; Muzzammil, N and Daryl, J T (2014). Biogas capturing and utilization from palm oil mill effluent. MPOB, Bangi.

Loh, S K; Nasrin, A B; Mohamed, A S; Nurul, A B; Muzzammil, N; Daryl, J T; Stasha, E R A; Lim, W S; Choo, Y M and Kaltschmitt, M (2017). First report on Malaysia's experiences and development in biogas capture and utilization from palm oil mill effluent under the Economic Transformation Program:
Current and future perspectives. Renewable and Sustainable Energy Reviews, 74: 1257-1274.

Mauskar, J M (2008). Guidelines on odour pollution and its control. Delhi. Central Pollution Control Board.

Startsev, A N (2017). The reaction mechanisms of H2S decomposition into hydrogen and sulphur: Application of classical and biological thermodynamic. J. Thermodynamic and Catalysis, Vol. 8 Issue 2. DOI: 10.4172 / 2157 - 7544.1000186.

Van Harreveld, A P (2001). From odorant formation to odour nuisance: New definitions for discussing a complex process. Water Science and Technology, 44(9): 9-15. 